given him permission to get up. Pulse 80 , with nearly its proper fulness and strength; respiration 17 , not thoracic.

Such is the history of the case which I find in my note-book, taken now four years ago. I have had the boy (or rather now young manl) under my observation from time to time ever since. He made a speedy and perfect recovery; within a fortnight he was walking about as well as ever; but the spleen began to increase in size, and at last was nearly as large, thongh never quite, as it had been before the accident. I last saw the patient about six months ago; he was then a tall and tolerably fine young man of eighteen, but still very spare; his aspect was much more healthy, and he has lost the cyanotic look that he had before. The spleen was nearly of its old dimensions, its anterior border reaching as far as the middle line; it gave him, however, no inconvenience, and in no way incapacitated him for the pursuit of his avocation.

I feel myself quite unable to offer any explanation of the phenomena of the case, exeept the one that occurred to me at the time. But how it was that the boy escaped the common result of stch a catastrophe-death from hæmorrhage, or how it was that the peritonitis was not more severe, I feel myself equally unable to say. Was the hæmorrhage stopped by a coagulum? Did the contraction of the organ itself in some way arrest the bleeding? Did that contraction so alter the position and relation of the parts that the lacerated surface, previously free, was brought under the pressure of some neighbouring organ? With regard to the slightness of the peritonitis, we know that serous nembranes are sometimes tolerant of blood, and that the young will bear with impunity what older people will not. On reflection, I think that the idea that the sudden diminution of the size of the spleen might have been caused by the rupture of some cyst of which it was the seat is untenable; for both the enlarged, and subsequently diminished organ, retained the proportion of the ordinary healthy spleen, the outline being the same, and the notches in the former large and distant, in the latter smaller and more approximated. The reduction of size evidently depended on an equable contraction of the whole organ.

I have only to say, in conclusion, that I shall be very happy to show this lad to any one who would like to have ocular demonstration of his present condition.

Montague-street, Russell-square, October, 1857.

ON TWO CASES OF

\section{FRACTURE OF THE BASE OF THE CRANIUM.}

By W. O. EASTWOOD, M.D., Toronto University.

Having just completed attendance on the second of two cases of fracture through the base of the cranium, to which I have been called since the beginning of the present year, in both of which the issue has been fortunate, I propose to offer a history of them, which will necessarily be rather concise, as I have kept no notes of either; but dependance may be placed on its accuracy so far as I give it.

On April 18th I was called to see R. $R$ walling of a steamboiler, weighing some tons, which, from the shifting of its supports, had dropped some four inches, whilst being moved into a saw-mill, he being underneath it in such a position that all thought he had sustained serious injury across the lower part of the chest, as that was the only part on which there was any pressure when they got to him. He had ejected a considerable quantity of blood from his mouth and nose, and it was still oozing quite rapidly from both ears. He complained mostly of pain across the chest; but on a careful examination I could detect no fracture of any of the ribs nor other hurt there. I then directed my attention to the head, concluding that all the blood which had been ejected from his mouth and nose had come from his head, either directly, or, having been swallowed in the first instance, had afterwards been vomited; and this opinion was confirmed a few days after by the patient himself. On examining the head, I could detect only a very slight depression behind the right ear. It was then admitted by some of those present that, as the boiler rolled a little when it dropped, his head might possibly have been caught between the corner of a piece of timber and the boiler; this, also, the patient confirmed when he said he distinctly remembered that the corner of the piece of timber caught him just behind the right ear (where I could detect the clepression), and the boiler on the opposite side, when he felt, to use his own words, as if his head went in with a noise. A glassy smoothness of the skin was now observable immediately over the depression, as if produced by severe pressure; but there was no appearance of ecchymosis till some days after the accident. For a number of days the patient slept continually, unless when aroused, which was accomplished without much difficulty. For three weeks there was a discharge from both ears, at first of blood, but it gradually changed to scrum; and for a longer time from the right ear. There was no delirium, except for one night about a week after the accident. For the first three or four days he vomited occasionally; on the third day there was slight ptosis of the right eye, and on the next day there was exophthalmia, eversion of the lower lid, and excessive odema of the conjunctiva, which increased in a few days so as to render it rather difficult to obtain a sight of the cornea. This œdema I could only account for by supposing that serum from the arachnoid had found its way through a fissure in the bone to the cellular tissue of the orbit and eyelids; as the ecchymosis spreading from the seat of the depression was very slight, and the cdema continued though the conjunctiva was several tirnes scarified after Tyrrell's method, the only effect produced being a temporary diminution of the swelling. In about six weeks he was so far convalescent as to be able to walk out, the progress from the beginning having been almost uniformly favourable.

This is as particular a description as I can give with accuracy so far, and I will now speak of the treatment adopted, and offer my reasons for it.

When reaction took place from the shock of the accident, the hair was cut as short as possible, cloths, wrung out frequently in cold water, applied to the scalp, and one drop of croton-oil administered; but no blood was drawn, because, from the frequent occurrence of inflammation after excessive losses of blood, the reaction so apt to follow venesection, (unless prevented by medicine, the administration of which I wished to avoid, and the quantity of blood which he had already lost, I thought that the croton oil would answer best the chief indica. tion for treatment-viz., the prevention of inflammation; and, moreover, I desired to save the patient's strength to enable his system the better to bear up against the injury of an organ so important to life as the brain, and to repair it; also in order that I might be able to employ venesection more freely when the first symptoms of inflammation should manifest themselves, I was not disappointed in the effect expected from the croton oil, for it abated the force and frequency of the pulse, and relieved the pain in the head so much that I considered venesection might still be withheld with advantage to the patient. I therefore continued the oil for three weeks, giving from one to three drops daily, as circumstances required, never allowing the bowels to remain unmoved more than twelve hours. On one occasion, when, from the disoust which the patient felt for the oil, it was not given by the friends according to direction, he became delirious, and I was sent for in the night, when I gave him two drops, and administered an injection of turpentine. On visiting him the next morning he was in a much more satisfactory state, the delirium having entirely ceased. After that he would ask for the oil, much as he disliked it, whenever he thought his bowels had remained too long confined. Except the discomfort given to the patient by the griping and frequent moving of the bowels, he experienced no bad effects from it. Whenever, from a longer interval having been allowed between the doses, there was an increase of the feverish symptoms, they invariably abated on the operation of the oil. Of this effect the patient himself was aware. During the entire treatment I drew no blood, for I found it unnecessary, nor did I apply any blister or other external irritant, for I regarded the oil as a sufficient connter-irritant as well as evacuant. This treatment was continued for about three weeks. Other purgatives were then substituted for the oil. In about three months he resumed his work. I omitted to state that he was a young man of good constitution and habits.

The second case, that of J. D-, a married man, aged about thirty, who was injured by the falling of a brick wall, his right hip-joint being dislocated, the inferior maxillary bone fractured through the neck on the right side, and the cranium fractured through the base. After a few hours spent in preparations for the reduction of the dislocation, and in waiting a short time, until the patient had in some measure recovered from the shock, the dislocation was reduced with little trouble.

The symptoms of injury of the head in this case were, bleeding from the left ear and mouth, strabismus of the right eye, distortion of the face, the mouth being drawn towards the 
right side, - the two symptoms just mentioned not being manifest till the second or third day, - and considerable stupor and pain in the head, after reduction had eased the pain in the hip. In the medical treatment of this case I was assisted by Dr. Ware, and its result was equally fortunate with the other. The treatment was similar to the last as regards the administration of croton oil, but in this case it was thought best to have recourse to venesection, when reaction had fully taken place, and also on the third day; because the patient had lost but little blood from the accident, and reaction was more violent than in the former case. He was also blistered on the nape of the neck about a week after the accident, a considerable abrasion on the back of the shoulder, which had discharged a good deal, having nearly healed at the time. A mercurial was also given several times, when the secretion of the liver was deficient. It is now six weeks since the accident, and the patient is able to walk out, with the assistance of a caue, though the strabismus and distortion of the face still remain. I will now close, and leave further comment to those more experienced than a young surgeon located in a Canadian village, merely adding that from my humble experience of the diurnal administration of croton oil, I accord in opinion with Dr. Fife as to its perfect safety. September, 1857.

\section{PARASTTICAL DISEASES AS INFLUENCED BY COOKING.}

BY B. DANIEL, Esq., M.R.C.S.E., L.S.A., Chelsea.

Ir has appeared to be a subject of scarcely less vital importance than wilful adulteration, that attention should be concentred on the innumerable parasitical animals which have been found to infest all parts of organised animals ; for microscopical researches have of late years pretty clearly shown that the larvæ of one species of parasitical insect, when introduced into the body, will give rise to the development, in different parts of the system, of parasitical creatures modified in their organisms and structures according to the particular dwellings assigned to them. It has been shown by direct experiment that cysticerci, the insects which constitute measled pork, are capable of being transformed into tæniæ when introduced into the alimentary passages of sheep, of dogs, or of rabbits. An experiment has been made on the body of a criminal, and anthenticated by indisputable evidence, which has proved by ocular demonstration, after death, the existence of young tæniæ (tænia solium) in the duodenum and the small intestines, resulting from the administration of cysticerci during life. It has also been shown that coenures, ${ }^{*}$ by their presence and accumulation in the brain and spinal cord of sheep, produce pres. sure on those organs and cause vertigo in them, popularly designated as the "staggers." These cænures are said, by some observers, to be convertible into the cysticerci of pork, and to be also capable of developing themselves into tæniæ.

There is a strong tendency in recent observations to establish a theory that development of parasitical animals is determined by the particular medinm which they inhabit; that, in the highest state of development, the same species of larvæ which develope themselves into tæniæ, lumbricoides, or ascarides, in the intestines, may in other parts of the body be converted into hydatids and acephalocysts of all sorts; that, also, the larvæ of the higher-developed creatures can undergo a retrogressive process, and that ova of tapeworm are thus convertible into cysticerci.

In investigations into the microscopic world, observers are lost in wonder at the small beginnings of animated nature. Infusoria originate in an unaccountable manner. If we boil dried juice of cabbage in distilled water, in a few days glau comæ are found; creatures capable of locomotion, with a slit for a mouth, and multiplying themselves by subdivision and germination. There are minute parasitical bodies which tax the ingenuity of the most learned, patient, and practised observers to determine to what kingdom they belong, whether animal or vegetable, or whether, as in the particular instance

* There is a peculiar metamorphosis of the cyst of the cysticercus, which, in some cireumstances, acquires the faculty of putting forth buds on its surface, which develop themselves, and thus form a colony of cysticerci implanted Rod. Leuckart, "Du Parasitisme et des Purasites," in Archiv. für Pbysiol., Heilkunde, 1852.) of intestinal worms, they are, as Henle observes, "a link in the series of development of helminthes." It does not appear an extravagant idea that the germs of disorders in the animal constitution may have their origin in the introduction of these infinitesimal organisms into the body. In the instance of cholera, London experience has shown how much it is influenced by the quality of water supplied to its inhabitants, and much of this water is full of animal and vegetable organisms. It remains to be shown how much of disease may be attributable to the quality of food supplied, - how many cysticerci may be contained in pork sausages, - how many trichinæ spirales in the flesh of birds and beasts, - and how many other abominanations are unwittingly consumed by an innocent public.

To prove that if one animal feed upon another infested by parasitical insects it becomes a prey to the same parasites in its turn, I would give the following experience, taken from No. III. of the Quarterly Journal of Microscopical Science, $1853:-$

"M. Herbst, in 'Fxperiments on the Transmission of Intestinal Worms,' had fed a female badger on vegetables and remains of animals which he had dissected. It died at two years old, and an infinite number of trichinæ were found in all the voluntary muscles.

"The flesh of the badger was given to some young dogs about six weeks old, and was devoured by them in the course of a few days. One of the puppies was sent into the country, and allowed to be at large, exposed to all the usual external influences. On the examination of the other two, made on the 10 th and 18th of February, 1851, all the voluntary muscles were found to be as abundantly infested with the trichinæ as were those of the badger which the puppies had devoured three months before." The third dog, which had been sent into the country, was not examined until nine months after, and although apparently healthy and vigorous, it was found, on a microscopic examination of the sterno-mastoid muscle, that there were innumerable cysts of these trichina. The author expresses his inability to account for the transmission of the ova of these animalcules through the current of the blood into the tissues, which he supposes to take place from the uniform distribution of the insects through the muscles of the voluntary system.

With respect to cysticerci, I should wish to draw attention to "Notes of a Microscopical Examination of 'Measled' and other Pork," by Wm. Smith, F.L.S., Professor of Natural History, Queen's College, Cork, published in the number for October, 1856, of the Micrascopical Journal previously quoted.

In a commercial community, whatever touches the pocket is sure to receive its due meed of scientific investigation. In the south of Ireland, the leading article of commerce is pickled pork, which is supplied largely to Government and to the mercantile marine. 'The presence of "measles" in pork depreciates its quality as an article of food, and necessarily reduces its commercial value-" the market-price is lowered," ergo, "an attempt was lately made by the provision merchants of Cork to arrive at more certain conclusions respecting the nature and extent of the disease, and its precise influence on the character and condition of the flesh affected by it." Mr. Smith observes: "Nineteen specimens were supplied to me--viz.,

6 of healthy fresh pork from various parts of different pigs;

6 of fresh muscle, 'slightly measled;'

6 of fresh muscle, 'badly measled ;'

1 of cured pork, "badly measled."'

And his conclusions are, that the disease of measled pork is owing to the presence of the "cysticercus cellulosæ," an insect contained in a rugose membrane, forming a bag or cyst, which, if inflated, extends to the size of one-third of an inch. The cyst contains the insect, which, coiled up, measures, on an average, one tenth of an inch. These cysts are imbedded between the fasciculi of the muscle, and, collapsing after the death of the pig, give the measly flesh a flabby appearance. The animal is described as consisting of " a slightly enlarged head, and a neck formed of numerous rings, gradually enlarged into a bladder-like vesicle, which constitutes the body of the worm." "The head of the cysticercus is provided at its extremity with a circlet of abont twenty-four hooklets, immediately beneath which are situated four circular organs." The hooklets, when farther magnified, present a stem fixed in the flesh of the head, a barb, and a sickle-like point. Mr. Smith agrees with most of the eminent physiologists of the present day, that the cysticerous of the pig is the "scolex"- that is, the intermediate or arrested condition of the tænia solium or tapeworm of man or other mammalia, and that the experiments made on dogs or other quadrupeds place the fact beyond a doubt. He concludes by saying, that "no 